\title{
FACULTY POSITIONS IN ACTUARIAL SCIENCE AND/OR MATHEMATICAL FINANCE IN THE ROBINSON COLLEGE OF BUSINESS AT GEORGIA STATE UNIVERSITY
}

The Department of Risk Management and Insurance in the Robinson College of Business at Georgia State University invites applications for one or more tenure track positions in Actuarial Science and/or Mathematical Finance to begin in fall 2008. The positions are open in rank and salaries and teaching loads will be competitive. (GSU log number 09-0628)

\section{JOB QUALIFICATIONS:}

Candidates should have a Ph.D. or, for the assistant professor level, expect to complete the degree requirements by August 2008 in actuarial science, mathematical finance, or a related field such as financial econometrics, economics, finance, or statistics. Successful applicants will have strong research capability in actuarial science, mathematical finance, or a closely related field. Candidates at the senior level (associate or full professor) should have strong publication records in the leading journals and should have a commitment to continue engaging in a highly productive research program.

\section{ABOUT THE ENVIRONMENT:}

The Department of Risk Management and Insurance is one of the oldest and most influential risk management programs in the world. The Department houses the largest actuarial science program in the U.S. and recently has been building research and academic programs in quantitative finance. The Department has a distinguished history of producing students who become leaders in the risk management professions.

\section{FURTHER INFORMATION AND APPLICATION PROCEDURE:}

Information about the department is online at www.rmi.gsu.edu. For further information, contact the chair of the search committee. Applicants should send a curriculum vita, a statement of research interests and teaching experience, three letters of recommendation, and recent publications or working papers to rmijob@gsu.edu; put search \#1 in the subject line. If necessary, you can send application materials by mail to:

\author{
Dr. Shaun Wang \\ Search Committee Chair \\ Department of Risk Management and Insurance \\ Robinson College of Business \\ Georgia State University \\ P.O. Box 4036 \\ Atlanta, GA 30302-403 \\ Tel: 404-651-2736
}


Applicants are strongly encouraged to submit their materials electronically via e-mail. Preference will be given to applications received by December 1, 2007; applications will be reviewed until positions are filled.

These positions are contingent upon on final budget approval by the university.

Georgia State University is an equal opportunity educational institution/affirmative action employer and encourages applications from qualified minorities. 